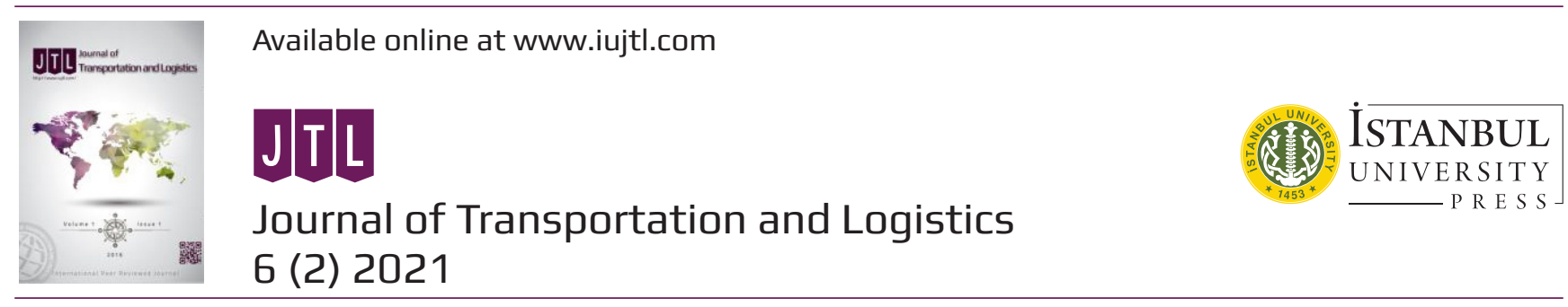

\title{
Evaluating Occupational Health and Safety Applications: A Framework for Turkish Container Ports
}

\author{
Seyhun Çoban ${ }^{1}$ (D), Hakan Demirel ${ }^{2}$ (D), Umur Bucak ${ }^{3}$ (D)
}

\begin{abstract}
With the COVID-19 pandemic, sky-high demand for long-distance shipping and remaining incapable of other modes to comply with maritime transport for meeting demand caused port congestion in vital hubs. The situation increased speed pressure that exists for so long on ports. In the meantime, operational speed requirements, port congestions, spread of port services threaten occupational health and safety in port areas. To cope with this risk many regulations and measures were taken by port authorities. In this study, it is aimed to determine the priority levels of the OHS rules applied to prevent possible risks and accidents in container ports. It has also been attempted to evaluate which factors are more effective in the implementation of these rules. Thus, occupational health and safety rules applied in Turkish container ports were determined and evaluated by experts. By this means, these applications were prioritized in terms of their significance levels. In the scope of these applications, prominent factors that threaten occupational health and safety were approached. Thus, a framework related to occupational health and safety rules applied in Turkish container ports and factors threaten them was designated. This framework was analysed and the results brought employee awareness into the forefront to establish reliable occupational health and safety system in Turkish container ports.

Keywords: Occupational Health and Safety, OHS Applications in Container Ports, Fuzzy AHP-TOPSIS Hybrid Method
\end{abstract}

1 Seyhun Çoban / Zonguldak Bulent Ecevit University, Institute of Social Sciences, Zonguldak, Turkey, E-mail: seyhuncbn@gmail.com, ORCID: 0000-0002-4819-3900

2 Hakan Demirel / Zonguldak Bulent Ecevit University, Maritime Faculty, Zonguldak, Turkey, E-mail: hakandemirel@beun.edu.tr, ORCID: 0000-0002-7579-7064

3 Corresponding author: Umur Bucak / Zonguldak Bulent Ecevit University, Maritime Faculty, Zonguldak, Turkey, E-mail: umurbucak@gmail.com, ORCID: 0000-0001-5112-8133

Citation: Coban, S., Demirel, H. \& Bucak, U. (2021). Evaluating occupational health and safety applications: a framework for Turkish container ports. Journal of Transportation and Logistics, 6(2), 137-147. https://doi.org/10.26650/JTL.2021.972109 


\section{Introduction}

Ships have transported $85 \%$ of the total global cargoes between ports (Brooks and Faust, 2018) due especially to maritime transport's unit cost advantage. With the COVID-19 pandemic, long distance or transoceanic shipping activities' significance was more specifically emerged. Sky-high demand for shipping and failure of other modes on keeping in step with maritime transport caused port congestion in vital locations for global trade. These circumstances increased speed pressure that exists for so long on ports. For this reason, man-machine interaction in port areas has further tightened. On the other hand, the need for operational speed, port congestions, pressures on port services, etc. threaten occupational health and safety (OHS) in port areas. To cope with this risk many regulations and measures were taken by port authorities. Moreover, almost every port that gives service to global trade has its own OHS department and operations have been controlled in the scope of OHS regulations and employees have been trained periodically by OHS department.

The International Labour Organization (ILO) and the International Maritime Organization (IMO) have made international regulations on OHS in port areas except for those where national policies or legislation for ports were made. The ILO made its first regulation entitled 'Protection against Accidents (Dockers) Convention' in 1929. It was updated with subjects such as health and security conditions, prosperity and vocational training, social working conditions, in the recommendation no.145 in 1973. Finally, the ILO released 'The Occupational Safety and Health (Dock Work) Convention' in 1979 and subsequently endorsed Recommendation No.160 (Hanaz, 2019:15-16). On the other hand, the IMO also made regulations specific to ports in the scope of OHS. First, the 'International Convention for Safe Containers' was released in 1972 and lastly the 'International Ship and Port Facility Security Code (ISPS Code)' was added to 'The International Convention for the Safety of Life at Sea (SOLAS-1974)' in 2004 (Sayg1, 2018: 22). Turkey has been a party to these regulations and conventions and related clauses have been applied in Turkish ports. Besides these international regulations, clauses of national Occupational Health and Safety Law No. 6331 have also been applied in Turkish ports.

Gutierrez and Hintsa (2006) displayed the importance of employee training to provide occupational safety in logistics systems. Beheary et al. (2020) supported them and featured the training for, and education level of employees to make the OHS system perform well. Antao el al. (2016) brought out indicators of OHS performance at ports and ranked them as a result of a frequency analysis. Yorulmaz and Aksu (2021) also assessed the OHS performance of ports and emphasized the importance of an awareness stage regarding this. Some studies featured human factors as a one of the main contributors related to OHS in maritime logistics. Uğurlu et al. (2015) handled collision and grounding accidents of tanker ships and revealed that human factors are the most prior factors in the accidents and their economic consequence became prominent. Mollaoglu et al. (2019) evaluated factors that cause occupational accidents in port areas and found that 'Overconfidence and Disengagement of Employees' is the most significant factor that affect OHS in port areas. Finally, Gul (2020) proposed a risk assessment framework for ports to reduce risks 
to an acceptable level and the likelihood and severity of the OHS risks in a port area were evaluated. In this study, OHS applications in Turkish container ports were prioritized in terms of their abatement level on OHS risks and threats or violating factors on these applications were evaluated.

In the second part, the methodology of this study is introduced and its implementation steps with formulations are displayed. In the following part of the second one, application of the method to framework of this study is explained. In the conclusion, the results are interpreted in the scope of the OHS system in Turkish ports.

\section{Methodology}

First, a questionnaire to be analysed by multi-criteria decision making methods to gain expert opinion was formed. Ethics committee approval was received to implement this form in the field study by Zonguldak Bulent Ecevit University, Human Investigations Ethics Committee in May, 2021.

The Analytic Hierarchy Process (AHP) method developed by Thomas L. Saaty (1980) has been used for solving problems and prioritizing criteria that are contributors in the decision making process. On the other hand, classic AHP may not fulfil the basic necessities of the problem when it comes much more criteria or uncertainty circumstances (Mollaoglu et al., 2019). At this juncture, fuzzy logic avoids sharp and subjective decisions that were involved in the decision making process (Demirel et al., 2018). The first study employed the Fuzzy AHP method, written by Laarhoven and Pedrycz (1983). Later, Buckley (1985) contributed the method by using geometric mean. In this study, we employed Buckley's proposed Fuzzy AHP method to prioritize the whole criteria. Afterwards, the weights of each criterion were used to rank alternatives by the Fuzzy TOPSIS method. The application steps of Fuzzy AHP-TOPSIS Hybrid method were introduced as shown below.

\subsection{Fuzzy AHP Application Steps}

Step 1: Pairwise comparison matrices consisting of criteria were established by the help of expert evaluations. Each element of the pairwise comparison matrices $\left(a_{i j}\right)$ was a fuzzy number that corresponding to linguistic terms. Therefore, pairwise comparison matrices as follows:

$$
\tilde{A}^{k}=\left|\begin{array}{cccc}
1 & \tilde{a}_{12} & \ldots & \tilde{a}_{1 n} \\
\tilde{a}_{21} & 1 & \ldots & \tilde{a}_{2 n} \\
\vdots & \vdots & \ldots & \vdots \\
\tilde{a}_{m 1} & \tilde{a}_{m 2} & \ldots & 1
\end{array}\right|
$$

where $\left(\tilde{a}_{i j}\right)$ represents the expert's valuation on comparison of $i$ th element with $j$ th element.

In this method triangular fuzzy numbers were identified to compare criteria by utilizing various linguistic variables such as "equal importance", "weak", "moderate importance", 
"moderate plus", "strong importance", "strong plus", "very strong", "very strong plus" and "extreme importance". This fuzzy nine level scale was displayed in Table 1 (Jiang and Fan, 2002).

Table 1. Triangular Fuzzy Numbers

\begin{tabular}{|l|c|c|c|}
\hline Real Numbers & $\begin{array}{c}\text { Linguistic } \\
\text { Variables }\end{array}$ & $\begin{array}{c}\text { Triangular Fuzzy } \\
\text { Numbers }\end{array}$ & $\begin{array}{c}\text { Reverse Triangular } \\
\text { Fuzzy Numbers }\end{array}$ \\
\hline 1 & Equal Importance & $(1,1,1)$ & $(1,1,1)$ \\
\hline 2 & Weak & $(1,2,3)$ & $(1 / 3,1 / 2,1)$ \\
\hline 3 & Moderate Importance & $(2,3,4)$ & $(1 / 4,1 / 3,1 / 2)$ \\
\hline 4 & Moderate Plus & $(3,4,5)$ & $(1 / 5,1 / 4,1 / 3)$ \\
\hline 5 & Strong Importance & $(4,5,6)$ & $(1 / 6,1 / 5,1 / 4)$ \\
\hline 6 & Strong Plus & $(5,6,7)$ & $(1 / 7,1 / 6,1 / 5)$ \\
\hline 7 & Very Strong & $(6,7,8)$ & $(1 / 8,1 / 7,1 / 6)$ \\
\hline 8 & Very Strong Plus & $(7,8,9)$ & $(1 / 9,1 / 8,1 / 7)$ \\
\hline 9 & Extreme Importance & $(8,9,9)$ & $(1 / 9,1 / 9,1 / 8)$ \\
\hline
\end{tabular}

Table 2. Alternatives' Fuzzy Scores and Linguistic Variables

\begin{tabular}{|l|c|c|}
\hline Real Numbers & Linguistic Variables & Triangular Fuzzy Numbers \\
\hline 1 & Absolutely Poor & $(0,1,2)$ \\
\hline 2 & Very Poor & $(1,2,3)$ \\
\hline 3 & Poor & $(2,3,4)$ \\
\hline 4 & Medium Poor & $(3,4,5)$ \\
\hline 5 & Fair & $(4,5,6)$ \\
\hline 6 & Medium Good & $(5,6,7)$ \\
\hline 7 & Good & $(6,7,8)$ \\
\hline 8 & Very Good & $(7,8,9)$ \\
\hline 9 & Absolutely Good & $(8,9,9)$ \\
\hline
\end{tabular}

Step 2: The geometric mean of each row of matrices was calculated to prioritize the whole criteria. At first, the geometric means of the first coefficients in each row's triangular fuzzy numbers were calculated.

$$
\begin{gathered}
a_{1 l}=\left[1 \times a_{12 l} \times \ldots \times a_{1 n l}\right]^{1 / n} \\
a_{2 l}=\left[a_{21 l} \times 1 \times \ldots \times a_{2 n l}\right]^{1 / n} \\
\ldots \\
a_{i l}=\left[a_{n 1 l} \times a_{n 2 l} \times \ldots \times 1\right]^{1 / n}
\end{gathered}
$$

And then, the geometric means of each row's triangular fuzzy numbers' second and third coefficients were also assessed respectively.

$$
\begin{gathered}
b_{1 m}=\left[1 \times b_{12 m} \times \ldots \times b_{1 n m}\right]^{1 / n} \\
b_{2 m}=\left[b_{21 m} \times 1 \times \ldots \times b_{2 n m}\right]^{1 / n} \\
\ldots \\
b_{i m}=\left[b_{n 1 m} \times b_{n 2 m} \times \ldots \times 1\right]^{1 / n}
\end{gathered}
$$


The geometric means of the third coefficients were measured as follows:

$$
\begin{gathered}
c_{1 u}=\left[1 \times c_{12 u} \times \ldots \times c_{1 n u}\right]^{1 / n} \\
c_{2 u}=\left[c_{21 u} \times 1 \times \ldots \times c_{2 n u}\right]^{1 / n} \\
\ldots \\
c_{i u}=\left[c_{n 1 u} \times c_{n 2 u} \times \ldots \times 1\right]^{1 / n}
\end{gathered}
$$

The sum of the geometric means in the row is $a_{1 s}$ for the lowest coefficients, $a_{2 s}$ for medium one and $a_{3 s}$ for the highest coefficients. Lastly, $\tilde{r}_{i j}$ matrix was gained by utilizing the values of $a_{i j}$.

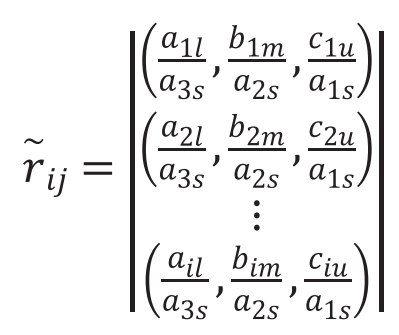

Step 3: Fuzzy weights were assessed based on the equation 6 as shown below:

$\tilde{U}_{i}=\sum_{j=1}^{n}\left(\tilde{W}_{j} \tilde{r}_{i j}\right), \forall i$.

In equation 6, " $\tilde{U}_{i}$ " referred to utility level of $i$ th criterion, " $\tilde{w}_{j}$ " referred to weight of the $j$ th criteria. Plus, $\tilde{r}_{i j}$ referred to the performance of the $i$ th alternative for the $j$ th criteria.

Step 4: Fuzzy numbers were transformed into crisp numbers. $\tilde{A}=(l, m, u)$ can be transformed into a crisp number by operating the equation below:

$A=\sqrt[3]{(l * m * u)}$

Step 5: After the defuzzification step Consistency Index (CI) was calculated in equation as follows:

$$
C I=\frac{\left(\lambda_{\max }-n\right)}{(n-1)}
$$

CI value should be below 0.10 .

Step 6: In the last stage, the best alternative was ranked as the highest value through the lower value. After that TOPSIS method was applied for choosing the best alternative.

\subsection{Fuzzy TOPSIS Application Steps}

TOPSIS (Techniques for Order Preference by Similarity to Ideal Solution) method was developed by Hwang and Yoon (1981) to solve the multi-criteria decision-making problems. In accordance with this method, the best alternative should be the nearest to the positive ideal solution and the farthest to the negative ideal solution. Application steps of the TOPSIS method were presented below:

Step 1: The Decision matrix was normalized by the help of equation 9: 
$r_{i j}=\frac{w_{i j}}{\sqrt{\Sigma_{j=1}^{J} w_{i j}^{2}}}, j=1,2,3, \ldots, J, i=1,2,3, \ldots, n$

Step 2: The normalized decision matrix was multiplied with the weights of each criterion $w_{i}$ that were obtained from the Fuzzy AHP method.

$v_{i j}=w_{i} * r_{i j}, j=1,2,3, \ldots, J, i=1,2,3, \ldots, n$

Step 3: In this step, the Fuzzy Positive Ideal Solution (FPIS, $A^{*}$ ) and the Fuzzy Negative Ideal Solution (FNIS, $A^{-}$) were determined by the help of equation 11 and 12 .

$A^{*}=\left\{v_{1}^{*}, v_{2}^{*}, \ldots, v_{n}^{*}\right\}$ maximumvalues

$A^{-}=\left\{v_{1}^{-}, v_{2}^{-}, \ldots, v_{n}^{-}\right\}$minimumvalues

Step 4: The distance of each alternative from FPIS $d_{i}^{*}$ and FNIS $d_{i}^{-}$were calculated by the help of equation 13 and 14.

$d_{i}^{*}=\sqrt{\sum_{j=1}^{n}\left(v_{i j}-v_{j}^{*}\right)^{2}}, j=1,2, \ldots, J$
$d_{i}^{-}=\sqrt{\sum_{j=1}^{n}\left(v_{i j}-v_{j}^{-}\right)^{2}}, i=1,2, \ldots, J$

Step 5: After the calculation of the distances, the Closeness Coefficients $\left(C C_{i}\right)$ of each alternative were calculated (see eq. 15);

$C C_{i}=\frac{d_{i}^{-}}{d_{i}^{*}+d_{i}^{-}}, i=1,2, \ldots, J$

Step 6: By comparing $\left(C C_{i}\right)$ values, the ranking of the alternatives was determined.

\section{Application}

The increase in the volume of trade due to the developing industrialization of the world, the desire to transport cargoes long distances at once and in large volumes, and the low unit costs increase the share of maritime transportation in all transportation modes day by day. Ports, one of the most important components of maritime transport, are growing and developing rapidly in parallel with the innovations. Factors such as the increase in global maritime trade capacity, the development of ship sizes that require high volumes of cargo handling at one time, the expansion of the cargo segment, etc. force ports to handle and store faster, which may pose a threat to OHS in the port area. In this study, OHS practices in container ports in Turkey were determined and the effects and degree of impact of OHS factors were measured using fuzzy methods.

Under the title of OHS practices in container ports, 15 criteria and 3 alternatives were determined. In the process of creating criteria and alternatives, information was obtained from experienced OHS experts and the rules applied in ports were examined. A pairwise comparison matrix was established with the determined criteria. The pairwise comparison matrix was first constructed with linguistic expressions and then these linguistic 
expressions were translated into triangular fuzzy numbers. The matrix converted into analytical triangular fuzzy numbers was solved by the Fuzzy AHP method proposed by Buckley (1985), and the criteria were weighted. In the second stage, after the criterion weighting, the 3 alternatives determined within the scope of the study were ranked within themselves using the Fuzzy TOPSIS method proposed by Chen (2000). Criteria and alternatives are displayed in Table 3 with their definitions.

Table 3. Criteria and Alternatives of the Study with its Definitions

\begin{tabular}{|c|c|c|}
\hline Criterion Code & Criterion Name & Definition \\
\hline $\mathrm{C} 1$ & Protective Equipment Usage & $\begin{array}{l}\text { Obligation of protective equipment usage for the whole employees of } \\
\text { the whole stakeholders that operate in the port area. }\end{array}$ \\
\hline $\mathrm{C} 2$ & Submit to Warning Signs & $\begin{array}{l}\text { Complying with traffic warning and occupational safety caution signs } \\
\text { that are situated in the port area. }\end{array}$ \\
\hline $\mathrm{C} 3$ & Having OHS Training & $\begin{array}{l}\text { It is forbidden to employ people who have not received OHS training } \\
\text { within the port area. }\end{array}$ \\
\hline $\mathrm{C} 4$ & $\begin{array}{l}\text { Not Working without Work } \\
\text { Permit }\end{array}$ & $\begin{array}{l}\text { It is obligatory to obtain permission from authorized persons before } \\
\text { starting work within the port area. }\end{array}$ \\
\hline $\mathrm{C} 5$ & $\begin{array}{l}\text { Not Operating Vehicles Without } \\
\text { Protective Equipment }\end{array}$ & $\begin{array}{l}\text { It is forbidden to operate vehicles or daily entering trucks that do not } \\
\text { have trailer locks or shoes locked, lashing and protection equipment } \\
\text { within the port area. }\end{array}$ \\
\hline C6 & $\begin{array}{l}\text { Lock Control During Cargo Pick } \\
\text { Up and Release }\end{array}$ & $\begin{array}{l}\text { It is the port operators' responsibility to control and open and close the } \\
\text { trailer locks of the trucks in the port area. }\end{array}$ \\
\hline $\mathrm{C} 7$ & Observing Speed Limits & It is obligatory to observe speed limits for the whole vehicles. \\
\hline $\mathrm{C} 8$ & $\begin{array}{l}\text { Equipment Usage for Working } \\
\text { at Height }\end{array}$ & $\begin{array}{l}\text { Since working at height poses a health and safety hazard, the use of } \\
\text { appropriate and protective equipment is obligatory. }\end{array}$ \\
\hline C9 & $\begin{array}{l}\text { Not to be under the Cargo or } \\
\text { between the Stacks }\end{array}$ & $\begin{array}{l}\text { It is forbidden for all employees to stand under the suspended load in } \\
\text { the port area, to walk around the container stowage areas on foot, and to } \\
\text { step in between the stacks. }\end{array}$ \\
\hline $\mathrm{C} 10$ & $\begin{array}{l}\text { Not Getting Too Close to } \\
\text { Construction Equipment }\end{array}$ & $\begin{array}{l}\text { It is forbidden to approach the work equipment more than the safety } \\
\text { distances while the vehicles or cranes are operating during the operation. }\end{array}$ \\
\hline $\mathrm{C} 11$ & $\begin{array}{l}\text { Not Using Electronic Devices } \\
\text { such as Cell Phones while } \\
\text { Working }\end{array}$ & $\begin{array}{l}\text { It is forbidden to use distracting objects such as cell phones while } \\
\text { working within the port area. }\end{array}$ \\
\hline $\mathrm{C} 12$ & $\begin{array}{l}\text { Parking of Vehicles Outside the } \\
\text { Specified Area }\end{array}$ & $\begin{array}{l}\text { It is forbidden to park all vehicles (trucks/trailers/cars) entering the port } \\
\text { area on a daily basis outside the designated places. }\end{array}$ \\
\hline $\mathrm{C} 13$ & $\begin{array}{l}\text { Gas Measurement Control in } \\
\text { Closed Area }\end{array}$ & $\begin{array}{l}\text { It is obligatory to measure the gas before entering the closed areas } \\
\text { (inside the warehouse / inside the container, etc.) and to enter based on } \\
\text { the approval. }\end{array}$ \\
\hline $\mathrm{C} 14$ & $\begin{array}{l}\text { Taking no Action Related to } \\
\text { Private Vehicles During the } \\
\text { Operation }\end{array}$ & $\begin{array}{l}\text { Persons of all vehicles in the port area are prohibited from leaving their } \\
\text { vehicle while waiting for the loading/discharging queue, walking around } \\
\text { during the operation, and performing maintenance and cleaning related } \\
\text { to the vehicle. }\end{array}$ \\
\hline $\mathrm{C} 15$ & Wearing Seat Belts in Vehicles & $\begin{array}{l}\text { It is obligatory to wear seat belts while driving vehicles and construction } \\
\text { equipment within the port area. }\end{array}$ \\
\hline Alternative Code & Alternative Name & Definition \\
\hline A1 & Labour Induced Factors & Deficiencies originated from employees that threaten OHS. \\
\hline A2 & Equipment Induced Factors & Deficiencies originated from vehicles, cranes etc. that threaten OHS. \\
\hline A3 & $\begin{array}{l}\text { Coordination Deficiency } \\
\text { Induced Factors }\end{array}$ & Deficiencies originated from miscommunication that threaten OHS. \\
\hline
\end{tabular}

The study was conducted based on data obtained from 15 OHS experts working in Turkish container ports. Profiles of the experts are demonstrated in Table 4. It is shown that in Table 4, experts have a lot of experience and each of them are at least B Class OHS experts. 
Table 4. Profiles of the Experts

\begin{tabular}{|c|c|c|c|}
\hline \multirow{2}{*}{ Number of Experts } & \multicolumn{3}{|c|}{ Educational Status } \\
\hline & Bachelor & & MSc. \\
\hline \multirow[t]{3}{*}{15} & $80 \%$ & & $20 \%$ \\
\hline & \multicolumn{3}{|c|}{ Expert Class } \\
\hline & A Class & & B Class \\
\hline \multirow[t]{3}{*}{15} & $60 \%$ & & $40 \%$ \\
\hline & \multicolumn{3}{|c|}{ Job Experience } \\
\hline & $7-9$ years & $10-12$ years & $13-15$ years \\
\hline 15 & $46,67 \%$ & $40 \%$ & $13,33 \%$ \\
\hline
\end{tabular}

\section{Results}

In this study, OHS applications in Turkish container ports were determined and the reasons for the violation of these applications were investigated. In the analysis, firstly OHS applications were prioritized according to the data obtained from experts by the help of the Fuzzy AHP method. And then, prominent violation factors were ranked based on the weights of the OHS applications by the help of the Fuzzy TOPSIS method. Secondly, the significance levels of the OHS applications in Turkish container ports were revealed according to expert evaluations and were demonstrated in Table 5 .

Table 5. Weights and Ranks of the Criteria

\begin{tabular}{|l|l|c|c|c|c|}
\hline \multicolumn{2}{|l|}{ Criteria } & Weight & Ranking & Expert & $\begin{array}{c}\text { Consistency } \\
\text { Index }\end{array}$ \\
\hline C1 & Protective Equipment Usage & 0.0690 & 6 & Ex1 & 0.0494 \\
\hline C2 & Submit to Warning Signs & 0.0682 & 7 & Ex2 & 0.0087 \\
\hline C3 & Having OHS Training & 0.0673 & 8 & Ex3 & 0.0117 \\
\hline C4 & Not Working without Work Permit & 0.1299 & 3 & Ex4 & 0.0269 \\
\hline C5 & Not Operating Vehicles Without Protective Equipment & 0.0268 & 13 & Ex5 & 0.0248 \\
\hline C6 & Lock Control During Cargo Pick Up and Release & 0.0446 & 10 & Ex6 & 0.0204 \\
\hline C7 & Observing Speed Limits & 0.0401 & 11 & Ex7 & 0.0199 \\
\hline C8 & Equipment Usage for Working at Height & 0.0936 & 4 & Ex8 & 0.0272 \\
\hline C9 & Not to be under the Cargo or between the Stacks & 0.1374 & 1 & Ex9 & 0.0107 \\
\hline C10 & Not Getting Too Close to Construction Equipment & 0.1314 & 2 & Ex10 & 0.0133 \\
\hline C11 & Not Using Electronic Devices such as Cell Phones while Working & 0.0544 & 9 & Ex11 & 0.0219 \\
\hline C12 & Parking of Vehicles outside the Specified Area & 0.0143 & 15 & Ex12 & 0.0261 \\
\hline C13 & Gas Measurement Control in Closed Area & 0.0691 & 5 & Ex13 & 0.0276 \\
\hline C14 & Taking no Action Related to Private Vehicles During the Operation & 0.0346 & 12 & Ex14 & 0.0228 \\
\hline C15 & Wearing Seat Belts in Vehicles & 0.0191 & 14 & Ex15 & 0.0751 \\
\hline
\end{tabular}

As seen in Table 5, applications are 'Not to be under the Cargo or between the Stacks', 'Not Getting Too Close to Construction Equipment' and 'Not Working without Work Permit' became prominent criteria to provide OHS in port areas. On the other hand, the 'Parking of Vehicles outside the Specified Area' and the 'Wearing Seat Belts in Vehicles' were seen as subordinate criteria by the experts.

In the second phase of this study, prominent factors that cause to violate these OHS applications were ranked and the ranking table was displayed in Table 6. Accordingly, 'Labour Induced Factors' was seen as the most significant cause of being violated OHS applications in Turkish container ports. 
Table 6. Ranks of the Alternatives

\begin{tabular}{|l|c|c|}
\hline Alternatives & $\boldsymbol{C C}_{\boldsymbol{i}}$ & Ranking \\
\hline A1 (Labour Induced Factors) & 0,808 & 1 \\
\hline A2 (Equipment Induced Factors) & 0,617 & 2 \\
\hline A3 (Coordination Deficiency Induced Factors) & 0,380 & 3 \\
\hline
\end{tabular}

\section{Conclusion}

In container ports, the volume of cargo handled at one time is constantly increasing as a result of the increasing volume of trade and the size of the ships that allow more cargo to be transported at once. All these trends, such as the increase in the types of cargo carried in containers and ship capacities, put pressure on container ports in terms of operational speed. This situation may reveal threatening factors to OHS in port areas. In addition to operational speed pressure, technological developments are among the factors that threaten OHS in ports. With advancing technology and increasing mechanization, the importance of OHS has increased even more.

In this study, it is aimed to determine the priority levels of the OHS rules applied to prevent possible risks and accidents in container ports. It has also been attempted to evaluate which factors are more effective in the implementation of these rules. The criterion of 'Not to be under the Cargo or between the Stacks' was seen as the most important criterion by the experts. Accordingly, employees standing under a suspended load in the port area, walking around the port areas on foot, and entering the container stacks pose a threat to OHS. Among these threats, containers falling during handling operations, the overturning of a container and landing on the employees, etc. can be displayed. The prominence of this criterion reveals the importance of equipment reliability and employee awareness.

'Not Getting Too Close to Construction Equipment' was determined as the second important criterion. Construction equipment is constantly in motion in the port area and during operation. Getting too close to construction equipment beyond safety distances poses a threat to OHS. Being close to the construction equipment that stacks full and empty in the port area causes possible risks and accidents. Even though audible and visual warning detection systems and camera systems are used against risks in construction equipment, vital accidents can occur due to being in the instant working area or rapid movement of the equipment. Considering this criterion as a priority brings employee awareness to the fore in terms of ensuring OHS in ports.

'No Working without a Work Permit' was determined as the third important criterion. Works performed without permission in the port area, especially non-routine works, cause possible risks and accidents. In all works requiring a work permit in active work areas, permission should be obtained from authorized persons before starting work and information should be given to the relevant units about the work to be done. Obtaining the work permit will ensure that all security measures related to the work to be done will be taken and started. The priority of this criterion shows the importance of the level of coordination.

According to the analysis results obtained by applying the fuzzy AHP-TOPSIS hybrid method, Labour Induced Factors' emerged as the top priority alternative. While this 
alternative was followed by 'Coordination Induced Factors' as the second prior alternative, the 'Equipment Induced Factors' alternative was determined as the third prior alternative. In this context, the level of OHS problems that may arise primarily from personal omission is clearly seen in the results of the study. The necessity of complying with the rules, rather than individual preferences, comes to the forefront in criteria and alternative evaluations, especially during work-related activities.

With this study, which aims to create an effective awareness in OHS practices in terms of container ports, it is thought that the points that should be paid attention to in terms of employees and employers are expressed within a system with expert opinions and fuzzybased methods. In addition, it is foreseen that this study will create a basic perspective for the studies to be done for different port areas by taking different methods and a different number of expert evaluations.

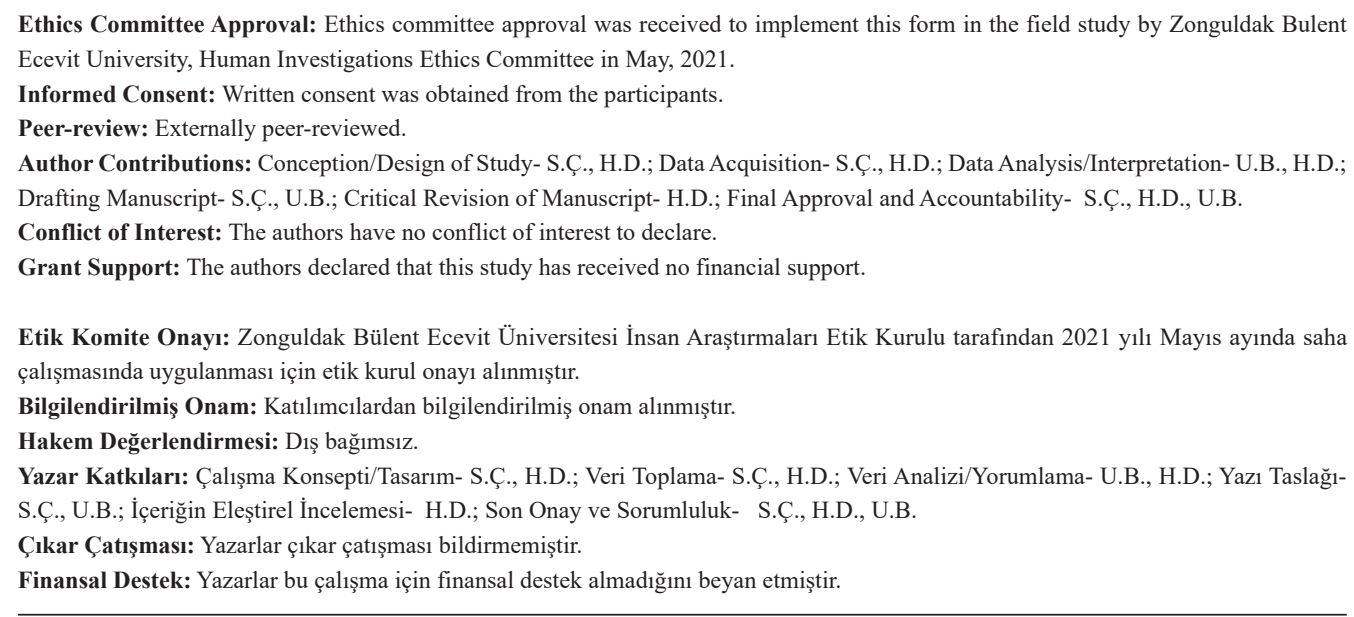

\section{References}

Antão, P., Calderón, M., Puig, M., Michail, A., Wooldridge, C., \& Darbra, R. M. (2016). Identification of occupational health, safety, security (OHSS) and environmental performance indicators in port areas. Safety science, 85, 266-275.

Beheary, M. S., Abdelaal, A., \& Matar, S. M. (2020). Occupational Health and Safety Practices Assessment in Damietta Port, North Egypt. Asian Journal of Advanced Research and Reports, 17-27.

Brooks, M. R., \& Faust, P. (2018). 50 Years of Review of Maritime Transport, 1968-2018: Reflecting on the Past, Exploring the Future, UNCTAD Publishing, Geneva. (No. UNCTAD/DTL/2018/1).

Buckley, J. J. (1985). Fuzzy hierarchical analysis. Fuzzy sets and systems, 17(3), 233-247.

Chen, C. T. (2000). Extensions of the TOPSIS for group decision-making under fuzzy environment. Fuzzy sets and systems, 114(1), 1-9.

Demirel, H., Balin, A., Çelik, E., \& Alarçin, F. (2018). A fuzzy AHP and ELECTRE method for selecting stabilizing device in ship industry. Brodogradnja: Teorija i praksa brodogradnje i pomorske tehnike, 69(3), 61-77.

Gul, M. (2020). A fuzzy-based occupational health and safety risk assessment framework and a case study in an international port authority. Journal of Marine Engineering \& Technology, 19(4), 161-175.

Gutierrez, X., \& Hintsa, J. (2006, May). Voluntary supply chain security programs: a systematic comparison. In The International Conference on Information Systems, Logistics and Supply Chain, Lyon, France. 
Hanaz, Muhammed Oğuzhan (2019). Konteyner Limanlarında Tehlike ve Risklerin Analizi, Unpublished Master Thesis, Üsküdar University Institute of Medical Sciences, İstanbul.

Hwang, C. L., \& Yoon, K. (1981). Methods for multiple attribute decision making. In Multiple attribute decision making (pp. 58-191). Springer, Berlin, Heidelberg.

Jiang, Y. P., \& Fan, Z. P. (2002). A practical ranking method for reciprocal judgment matrix with triangular fuzzy numbers. Systems Engineering, 20(2), 89-92.

Mollaoğlu, M., Bucak, U., \& Demirel, H. (2019). A quantitative analysis of the factors that may cause occupational accidents at ports. Journal of ETA Maritime Science, 7(4), 294-303.

Saaty, T. L. (1980). The analytic hierarchy process (AHP). The Journal of the Operational Research Society, 41(11), 1073-1076.

Sayg1, Erkan (2018). İzmit Körfezi Limanlarında İş Güvenliğinin Değerlendirilmesi, Unpublished Master Thesis, Kocaeli University Institute of Science, Kocaeli.

Uğurlu, Ö., Köse, E., Yıldırım, U., \& Yüksekyıldız, E. (2015). Marine accident analysis for collision and grounding in oil tanker using FTA method. Maritime Policy \& Management, 42(2), 163-185.

Van Laarhoven, P. J., \& Pedrycz, W. (1983). A fuzzy extension of Saaty's priority theory. Fuzzy sets and Systems, 11(1-3), 229-241.

Yorulmaz M., \& Aksu, A. (2020). Liman İşletmelerinde İş Sağlığı ve Güvenliği Uygulama Performans Boyutlarının AHP ile Değerlendirilmesi: Kocaeli Liman Bölgesi. Işsletme Bilimi Dergisi, 9(1), 1-24. 
